\title{
America's new leadership
}

\section{Researchers should keep a cool head about science under Obama, David Goldston argues.}

\begin{abstract}
Editor's note: This column, which went to press before the 4 November US election, is written based on the poll indicators at the time - which pointed strongly towards a Democratic victory.
\end{abstract}

$T$ tor he US presidential campaign goes on for so long that it's hard to imagine life without it. But pundits and policy advocates can adjust quickly, shifting from speculating about who the president will be to speculating about what he will do. And when it comes to science, the victory of Barack Obama and the Democrats in Congress has created an enormous sense of anticipation.

Scientists' most immediate, and perhaps most fervent, concern is funding, and Obama's election does indeed portend better times. But for energy research, it is likely to be years before the numbers match the campaign rhetoric. Obama's proposal was to spend US $\$ 15$ billion a year on new energy technologies, research that receives only about $\$ 2$ billion a year today. Less advertised was that the new money would be raised through climate-change legislation. Under Obama's plan, the government would auction permits to allow industry to emit greenhouse gases under a bill to cap emissions.

But climate-change legislation remains controversial even among Democrats, and the economic downturn will make it even harder to enact early in the new administration. Moreover, Congress will probably allocate at least a portion of the permits for free, reducing the funds Obama wants to tap for research. And support is growing among economists and politicians for the idea of rebating most, if not all, of any auction revenue to taxpayers to alleviate the impact of higher energy prices, rather than using the money for government programmes.

Delaying a massive spike in energy spending might not be an entirely bad thing. The details of energy research programmes haven't been seriously rethought in years, and experts disagree on where government funds would be most helpful. In Congress, the discussion has largely been stuck on the philosophical question of whether government research can advance useful technology or does damage by distorting market forces. That debate has not progressed much since Ronald Reagan tried to eliminate most applied energy research

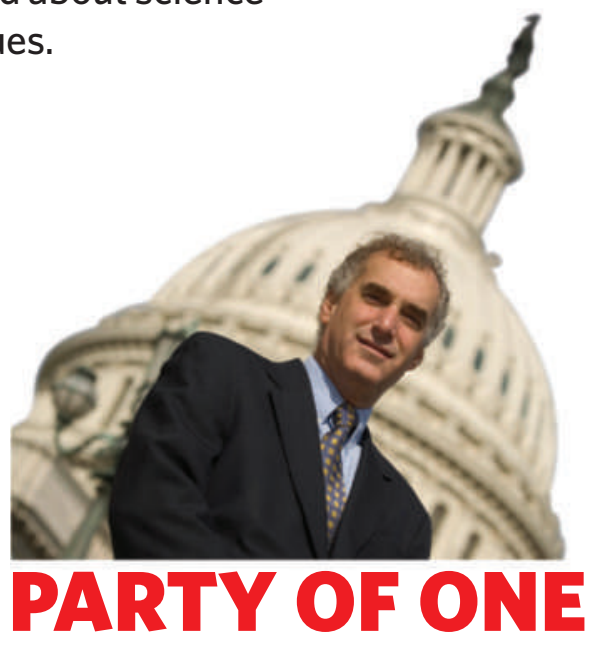

in the 1980s. Allowing time for a thoughtful review before spending $\$ 15$ billion - an arbitrary figure, in any event - couldn't hurt. In the meantime, there is plenty of energy research that could benefit now from a more incremental influx of cash, including work on batteries, commercial building efficiency and carbon sequestration.

Money is likely to be available for such initiatives. The financial crisis and economic slowdown will probably contribute to a boost in research spending. Concerns about the ballooning deficit are being eclipsed by the push to use government spending to stimulate the economy. And the size of the total domestic spending pie - which Obama wanted to enlarge even before the Wall Street meltdown - is always the best indicator of how much will be allocated to science.

Beyond that, science advocates will no doubt contend that research spending should be especially favoured in any economic stimulus package because it contributes to future economic growth. That line of argument may get science still more money even though research doesn't fit the profile of ideal stimulus spending - programmes that quickly get money into the hands of lower- and middle-income consumers who will spend it most rapidly.

So the question doesn't seem to be whether research budgets will fare better under Obama, but rather by how much. The budgets of the National Science Foundation, the National Institute of Standards and Technology (NIST) and the Office of Science at the Department of Energy are likely to be put on a path to double over 10 years, a move that both President George W. Bush and the Democratic
Congress have supported in principle. And doubling spending at the three agencies is relatively cheap; together they now spend about $\$ 11$ billion a year.

Obama has also called for a 10-year doubling of the budget of the National Institutes of Health (NIH), now about $\$ 30$ billion a year. The NIH is a popular cause, but it could face tough competition for dollars even in an expansive climate. The agency is funded through the same spending legislation that finances education and social-services programmes, which have more pent-up demands, larger constituencies and a higher profile. And the highest Obama priorities in health are improving care and expanding insurance coverage, not research. Also, in the wake of the doubling of the NIH budget from 1998 to 2003, Congress has begun to wonder aloud whether the additional spending resulted in enough tangible benefits for patients.

Increases for other agencies pose their own conundrums. For example, pushed by the need to garner votes in Florida and concerns about relying on Russia for its Soyuz spacecraft in the wake of the invasion of Georgia, Obama called for prolonging the life of the space shuttle and reducing the gap between the shuttle's retirement and the launch of a new vehicle for sending humans to the Moon. Doing that while launching more scientific satellites, which Obama also supports, would require a significant increase in NASA's \$17-billion budget. Congress could baulk at such a boost, leaving the agency in its usual predicament of too many missions and too little cash.

But the biggest unknown about science under Obama is what new initiatives he will propose. Unlike Bush, Obama has no philosophical qualms about government programmes to stimulate industrial innovation. Existing efforts such as the Technology Innovation Program (formerly the Advanced Technology Program) at NIST will probably get a new lease of life, and proposals from think tanks, such as the creation of a national innovation foundation, could get a closer look.

So the air of anticipation in the nation's laboratories and faculty clubs is not unfounded; the danger is that it will become excessive. Like all presidents, Obama will have to govern as a mere mortal, making trade-offs among legitimate claims on the public purse and crafting political deals among constituencies. Scientists are going to have to tame their insatiable appetite for dollars, and their tendency to see politicians as either with them or against them, for the current mood to survive much beyond the inauguration.

David Goldston is a project director with the Bipartisan Policy Center in Washington DC. 